\title{
MECHANISMS OF ACTION OF 5-BROMODEOXYURIDINE BASED ON STUDIES WITH TETRAHYMENA PYRIFORMIS
}

by

\author{
ANNE E. LYKKESFELDT \\ The Biological Institute of the Carlsberg Foundation, \\ 16, Tagensvej - DK-2200 N, Copenhagen, Denmark
}

Key words: Tetrahymena, BUdR, cell multiplication, macromolecular synthesis

The effect of BUdR on cell multiplication, DNA-, RNA- and protein synthesis in Tetrahymena pyriformis has been studied. Incorporation of BUdR up to $50 \%$ of the thymine sites in the DNA has no effect on the DNA synthetic rate at least for two generation times. RNA synthesis is inhibited shortly after addition of BUdR to exponentially growing populations, and experiments with synchronously growing populations have revealed that inhibition of RNA synthesis follows the incorporation of BUdR into the ribosomal RNA genes. A preferential inhibition of the synthesis of $25 S$ and $17 \mathrm{~S}$ ribosomal RNA has been found to take place at all degrees of BUdR substitution in DNA. Local changes in the structure of the DNA molecule leading to alterations in the pattern of transcription have been proposed as a model for the mode of action of BUdR. 


\section{CONTENTS}

1. Introduction

page

1.1 Effects of BUdR incorporation into the DNA molecule $\ldots \ldots \ldots \ldots \ldots \ldots \ldots \ldots \ldots \ldots, 47$

1.2 Effects on RNA synthesis of BUdR substitution in DNA $\ldots \ldots \ldots \ldots \ldots \ldots \ldots \ldots \ldots \ldots \ldots$

1.3 Effects on enzyme activities of BUdR substitution in DNA $\ldots \ldots \ldots \ldots \ldots \ldots \ldots \ldots \ldots . \ldots . \ldots$

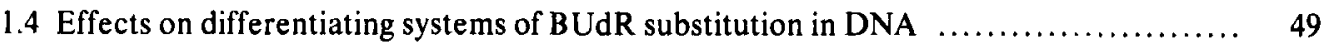

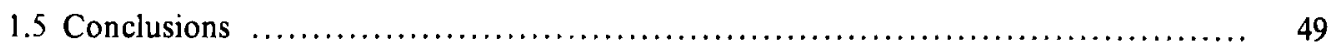

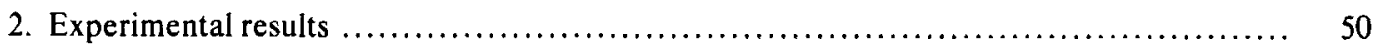

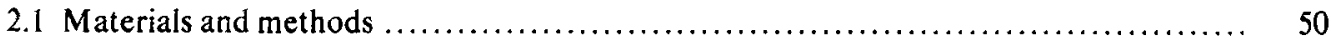

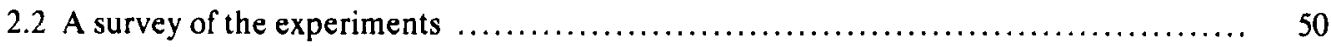

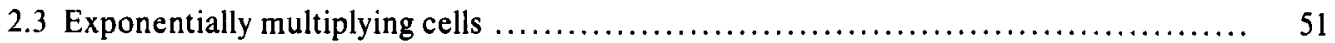

2.3.1 Growth conditions defining fixed degrees of BUdR substitution in DNA ....... 51

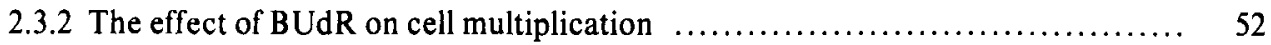

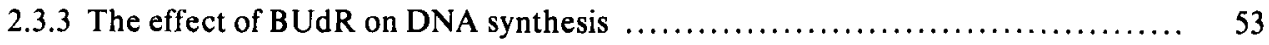

2.3.4 The effect of BUdR on RNA synthesis ................................. 55

2.3.5 The effect of BUdR on protein synthesis ............................... 56

2.3.6 A summary of the effects of BUdR on exponentially growing populations ....... 57

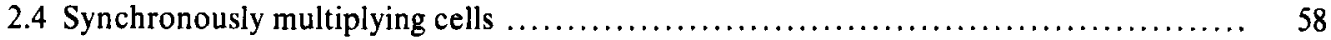

2.4.1 The effect of BUdR on synchronously dividing populations .................. 58

2.4.2 A summary of the effects of BUdR on synchronized populations .............. 60

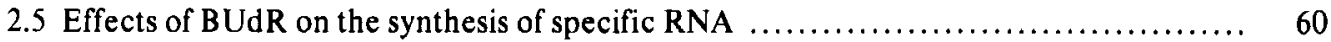

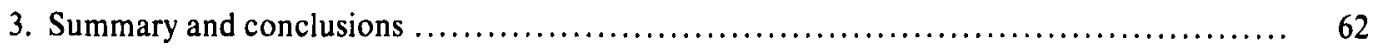

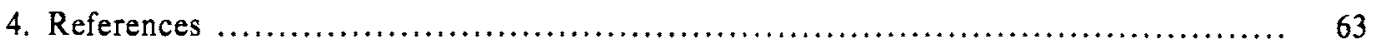




\section{INTRODUCTION}

The structural thymidine analog, 5-bromodeoxyuridine (BUdR) is useful for studies in molecular biology because it can be incorporated into DNA in place of thymidine. This faculty has been used in studies of DNA replication (56) and of the DNA replication sequence (9), taking advantage of the separation of BUdR-substituted DNA from normal DNA by equilibrium density gradient centrifugation in $\mathrm{CsCl}$ (42). BUdR-substituted DNA can be stained selectively with fluorescent dyes $(8,15)$, sister chromatids may stain differentially after replication in $\mathrm{BUdR}$, and sister chromatid exchanges may be visualized. Another selective staining technique for BUdR-substituted DNA depends on use of fluorescent antibodies against bromodeoxyuridine (22). Thus BUdR has been much used as a tracer compound for studies of normal processes occurring at the chromosomal level in living organisms.

However, BUdR has side effects on cell functions. Cell growth can be inhibited (25), normal development of differentiating systems be perturbed (46), activities of specific enzymes be reduced (51) and BUdR-substituted DNA be sensitized to irradiation (28). In 1945 Hitchings et al. found that bromouracil inhibits growth of Lactobacillus casei, and that growth inhibition can be counteracted by folic acid in the growth medium (25). In 1954 was demonstrated that bromouracil replaces thymine in DNA (14). Bromouracil occurs in keto and enol forms and this may lead to incorporation errors because the rare enol form pairs with guanine. BENZER and FREESE have examined mutagenesis by bromouracil and found specific mutations after growth in the presence of bromouracil (5). This could reflect a greater probability for bromouracil to occur in the rare enol form at specific sites in the DNA molecule, hereby leading to altered base sequences of DNA.

However, not all inhibitory effects of BUdR can be explained by mutagenesis. Most effects are reversed when BUdR is removed from the growth medium and replaced by thymidine (46). This is not easily reconciled with mutagenic theories of $B U d R$ action. Before these cells can divide after removal of BUdR they replicate their DNA $(19,38)$. Thus BUdR appears to have effects which depend on its incorporation into DNA, but not on mutations. The effects of BUdR on the synthesis of DNA, RNA and proteins as well as on differentiating systems shall be given in the following pages. Evidence shall be presented that incorporation of BUdR into DNA may lead to changes in the patterns of transcription. My own experiments to be presented at the end of this paper support this hypothesis.

\subsection{Effects of BUdR incorporation into the DNA molecule \\ Changes in the physical-chemical characte-} ristics of DNA can be noticed after incorporation of BUdR into the DNA molecules. The spectrum of the circular dichroism of DNA is different in BUdR-substituted and normal DNA (4).

Chromosomes which contain BUdR in both DNA strands appear less than normally condensed in certain areas (27). The melting point (defined as the temperature at which there is $50 \%$ increase in $\mathrm{OD}_{260}$ ) of BUdR-substituted DNA as well as of chromatin containing BUdRsubstituted DNA is different from what characterizes normal DNA and normal chromatin $(4,12)$. Change in the dissociation constant of chromatin containing BUdR-substituted DNA has been found (21). In E. coli the binding of lac-repressor to lac-operator is increased when the latter is substituted with BUdR (35). Since structural changes in the DNA may cause serious changes of normal cell functions precautions must be taken before BUdR is used as a tracer compound in studies of normal cellular processes. On the other hand, demonstrations of change in the structure of the DNA molecule after incorporation of BUdR may open up new possibilities of understanding the many inhibitory

Abbreviations: BUdR - 5-bromodeoxyuridine, THFA - tetrahydrofolic acid, PCA - perchlorid acid, TdR thymidine. 
effects of BUdR and thus in turn stimulate the utilization of BUdR.

\subsection{Effects on RNA synthesis of BUdR substitu- tion in DNA}

Relatively few investigations of the effect of BUdR on RNA synthesis are described in the literature, though many inhibitory effects of BUdR may be consequences of changes in the pattern of transcription after incorporation of BUdR into DNA. RNA synthesis in bacteria and bacteriophages is inhibited when BUdR is incorporated into the DNA. Furthermore BUdR-substituted DNA of lambda-phages seems less suitable as template for in vivo mRNA synthesis; JONES and DOVE have suggested that either the RNA polymerase may bind inefficiently to the bromodeoxyuridine-substituted DNA template, or the two DNA strands may have difficulty in strand-separation (29).

Hill, TSUBoI and Baserga (24) working with 3 T6 mouse fibroblasts in which $20 \%$ of the thymine sites in DNA were replaced with BUdR found that after removal of BUdR the cells show changes from the normal pattern of nucleoside incorporation into RNA. Adenosine and uridine incorporations are somewhat lower than normal, guanosine incorporation is three-fold increased. To the authors this mostly reflects synthesis of abnormal species of mRNA. Another possibility - which would harmonize with results for Tetrahymena to be presented later in this report - is that the proportion of the different species of normal RNA molecules is changed, and this might be measured as a change in nucleoside incorporation into RNA.

The error frequency in 5 S RNA from Chinese hamster cells grown in 5-bromodeoxyuridine has been investigated by STAMBROOK and WILliamson (50). The oligonucleotides from a $\mathrm{T}_{1}$-ribonuclease digest of $5 \mathrm{~S}$ RNA isolated from cells with $50 \%$ of the thymidine residues in DNA replaced by BUdR were analysed by fingerprinting techniques. The results suggest that misreading of BUdR-substituted DNA during transcription occurs at a very low level, if at all. The authors point out that they would not detect any alterations in oligonucleotides in $T_{1}$-ribonuclease digests of ribosomal $5 \mathrm{~S}$ RNA if the cells have mechanisms by which they can recognize and discard faulty RNA while allowing normal RNAs to be processed and to function.

From the described effects of BUdR on RNA synthesis may be concluded that BUdR can inhibit total RNA synthesis, and that BUdR-substituted DNA functions with reduced efficiency as template for mRNA synthesis. It is an open question whether BUdR-substitution in DNA causes synthesis of abnormal mRNA molecules. Possibly altered transcription patterns have not yet been measured directly as changes in the amount of specific RNA molecules, or in relative amounts of several specific RNAs.

\subsection{Effects on enzyme activities of BUdR substitution in DNA}

The incorporation of BUdR into DNA affects specific enzymes to different degrees. Some enzymes are activated (alkaline phosphatase (31)) while many are inhibited (tyrosine aminotransferase (52)) and others are unaffected (51).

Inhibition of tyrosine aminotransferase activity probably reflects reduced rate of enzyme synthesis. In any case BUdR induces neither an inhibitor of the enzyme activity nor a catalytically less active or less stable ezyme (52). STELLWAGEN and TOMKINS have therefore suggested that the inhibitory effect of BUdR on enzyme activities may result from reduction in the rate of normal mRNA synthesis rather than from synthesis of abnormal mRNAs. As a possible mechanism by which BUdR could preferentially inhibit transcription of certain genes, the promotors for some genes have been proposed to be more sensitive than others to replacement of thymine with bromouracil. Bromouracil in such promotors may reduce the frequency of mRNA initiation by RNA polymerase (52). Differences in the stability of specific mRNAs or of their corresponding proteins may also explain why BUdR inhibits enzyme activities differentially; incorporation of BUdR into DNA would reflect sooner on instable than on stable messengers or enzymes. Whatever the mechanism of action of BUdR in 
DNA, only one generation in BUdR-containing medium is required to produce differential effects at the level of enzyme activities. As mentioned, different hypotheses have been put forward to explain how BUdR substitution in DNA can lead to differential effects on enzymes, but none of these have yet received strong experimental support.

\subsection{Effects on differentiating systems of BUdR substitution in DNA}

Low concentrations of BUdR interfere with differentiation in many developing systems but have little influence on the proliferation rate and viability of the celts. In some systems BUdR inhibits the differentiation strongly and reversibly, normal development being resumed after removal of the BUdR (46). In other systems development continues abnormally during the BUdR treatment, and the effects are irreversible (46).

The high sensitivity of differentiating systems to even low BUdR substitution in DNA may reflect that normal development by cellular differentiation demands induction of new synthetic pathways at specific time points and repression of others, and even small changes in the concentration of one enzyme at a certain time may cause diversion from normal development. Thus, inhibition of myofibril formation in myoblast cells correlates with loss in ability to synthesize myosin (53) and inhibition of the development of hematocytoblasts into erythrocytes correlates with suppression of hemoglobin synthesis (43). In many other differentiating systems BUdR inhibits one or more enzyme activities, the appearance of which are part of the differentiation process $(1,57)$.

BisHOFF and HolTZER have supplied an interpretation why BUdR acts so relatively strongly in cellular differentiation and has minor effect on general growth. They suggest that genes coding for metabolic functions essential for cell growth might be relatively insensitive to BUdR substitution in DNA because - in contrast to many genes involved in differentiation - they do not possess an initiator region. Another possibility is that they exist in many copies in the cell (7). Extending the former hypothesis LIN and RIGGS have proposed that cellular functions which are subject to regulation are selectively inhibited by BUdR because BUdR-substituted DNA binds regulatory proteins tighter than does normal DNA (35). This may explain not only the high sensitivity to BUdR substitution of differentiating systems, but also the appearance of virus-like particles after growth of guinea pig cells (11), polyoma transformed cells (20), spleen cells (44), rat embryo cells (48) and mouse melanoma cells (49) in BUdR containing media. In all cases altered binding to DNA of regulatory proteins may result in disruption of finely adjusted regulatory systems which normally check viral growth (35). However, induction of virus-like particles could also reflect increased probability of strand breaks by which virus particles are released.

While no experiments contradict the view that BUdR exerts effects which are conditioned by the incorporation of the analogue into DNA, contributing different factors should not be disregarded. Thus HOLTZER et al. consider that the relatively small interval between the concentration of BUdR which produces no inhibition of the enzyme creatine phosphokinase to the one which leads to maximal inhibition may indicate that random incorporation of BUdR into DNA is not fully responsible for the observed effects of BUdR (26). However, to finally decide this matter measurements of BUdR substitutions seem required.

\subsection{Conclusions}

The described effects of BUdR indicate the existence of at least two mechanisms of action. 1) Mutagenic effects of BUdR are interpreted as reflections of a mispairing of BUdR in its rare enol form. However, mutagenic effets of BUdR must be rather small in eucaryotic cells since a BUdR-dependent cell line exists (hamster cells) which grows and multiplies nearly normally when all thymine sites in the DNA are filled with bromouracil (6). Furthermore, effects of BUdR which can be reversed by addition of thymidine are not likely to be mutagenic. 2) As another mechanism of action of BUdR has been suggested that incorporation of BUdR into DNA alters the pattern of transcription $(35,51)$. It has been 
shown that BUdR-substituted DNA has a structure different from normal DNA, and in bacteria has been demonstrated altered binding of a regulatory protein (lac-repressor) to BUdR-substituted DNA, clearly indicating the possibility of changes in the pattern of transcription from BUdR substituted DNA. Direct demonstration of altered relative amounts of specific transcriptional products after growth in BUdR has not been made yet, but the differential effect of BUdR on specific enzymes may reflect such changes.

\section{EXPERIMENTAL RESULTS}

\subsection{Materials and methods}

Tetrahymena pyriformis, amicronucleate strain GL, was grown axenically in the chemically defined growth medium described by Rasmussen and Modeweg-Hansen (45) with the modification that no tetrahydrofolic acid (THFA) was present in the vitamin stock. THFA(as Ca-salt of formyltetrahydropteroylglutamic acid) was added separately at the time of inoculation. The populations were grown in Erlenmeyer flasks with screw caps and in a layer of medium not exceeding $1 \mathrm{~cm}$. The flasks were kept at $28^{\circ} \mathrm{C}$ without shaking and aeration. The cells were allowed to grow for at least ten generations at the desired THFA concentration before samples were taken for estimation of generation time or synthesis of macromolecules. The cells were counted in an electronic cell counter after fixation with 1.25 $\mathrm{M}$ formaldehyde and dilution with $0.16 \mathrm{M}$ $\mathrm{NaCl}$.

Replication of DNA was determined by CsCl-gradient centrifugation of isolated DNA. The cells wete harvested, and DNA isolated and analyzed as described in (41). The degree of BUdR substitution was determined from the position of hybrid and normal DNA in the CsCl-gradient (41).

For determination of the chemical amount of RNA, samples containing around 50,000 cells were precipitated with the same volume of 1.2 $M$ perchlorid acid (PCA). The precipitates were resuspended in $1 \mathrm{ml} 0.3 \mathrm{M} \mathrm{NaOH}$ and placed at $37^{\circ} \mathrm{C}$ for 3 hours in order to hydrolyze the RNA. The samples were cooled in an ice bath, $500 \mu 1$ ice cold $1.2 \mathrm{M}$ PCA was added, and after $20 \mathrm{~min}$ in ice bath the resulting precipitates were removed by centrifugation and the absorbance of the supernatants containing the hydrolyzed RNA measured at 260 $\mathrm{nm}$ in a Zeiss Spectrophotometer.

The precipitates from the RNA determinations were used for determination of the protein content by the method of LoWRY et al. (36).

The rate of RNA synthesis was measured as the amount of ${ }^{14} \mathrm{C}$-uridine incorporated into trichloroacetic acid precipitable material after $45 \mathrm{~min}$ exposure to the labelled compound $(0.1$ ${ }_{\mu} \mathrm{Ci}{ }^{14} \mathrm{C}$-uridine was used per ml sample).

The isolation of RNA by phenol extraction followed by centrifugation in a linear $0.15 \mathrm{M}$ to $0.58 \mathrm{M}$ sucrose gradient is described in (41) together with the labelling procedure.

\subsection{A survey of the experiments}

It was the aim of this work to study the effects of BUdR on cell multiplication and on macromolecular syntheses in Tetrahymena pyriformis. The experiments have led to a hypothesis for the mode of action of BUdR.

Tetrahymena pyriformis is particularly suitable for studies of the effects of BUdR because its high nuclear ploidi (about fourty) permits that we ignore mutagenic effects. The effects of BUdR on cell multiplication, DNA-, RNA-, and protein syntheses were examined under different sets of conditions each defining a degree of substitution of thymine with bromouracil in the new DNA. BUdR was found to inhibit RNA synthesis soon after it had been added to exponentially multiplying cultures. However, studies with synchronously multiplying cells showed that inhibition of RNA synthesis is secondary to incorporation of BUdR in the genes which code for ribosomal RNA. What was initially measured as inhibition of total RNA synthesis may mostly be inhibition of ribosomal RNA synthesis. Further analysis has shown the same extent of inhibition by BUdR of $25 \mathrm{~S}$ and of $17 \mathrm{~S}$ ribosomal RNA, and the synthesis of these two large ribosomal RNA molecules is much more severely inhibited than the synthesis of RNA species of lower molecular weights. 


\subsection{Exponentially multiplying cells}

\subsubsection{Growth conditions defining fixed degrees of BUdR substitution in DNA}

The level of replacement of thymine with bromouracil in new DNA depends on the rate of endogenous thymidylate synthesis and on exogenous concentrations of thymine compounds and of BUdR. Experimental control of the degree of BUdR substitution in DNA requires control of all three variables. In Tetrahymena pyriformis the synthesis of thymidylate takes place via the thymidylate-synthetase reaction (13), and easy ways to control this reaction is to limit the amount of the coenzyme, tetrahydrofolic acid, or to vary the exogenous concentration of thymidine and/or BUdR in a chemically defined growth medium $(37,40,45)$.

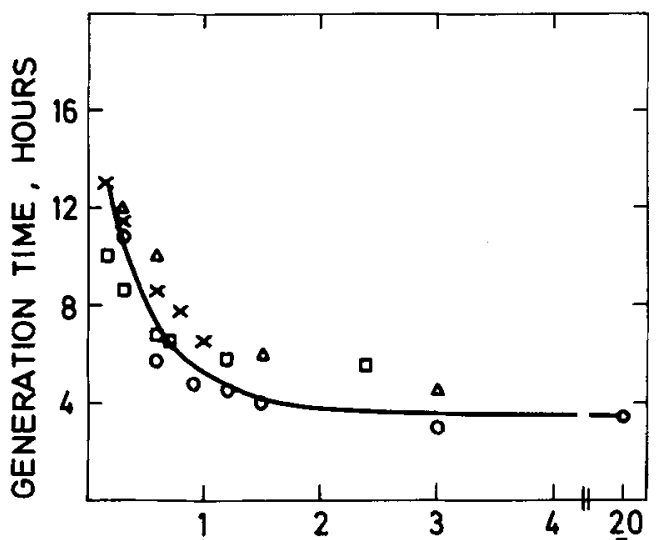

THFA CONCENTRATION $\left(\mathrm{mM} \times 10^{-5}\right)$

Figure 1. The generation time as a function of the THFA concentration. The generation time was estimated from exponentially growing cultures, which had grown at the desired THFA concentration for at least ten generation times.

As appears from Fig. 1 tetrahydrofolic acid is growth limiting in concentrations below $2 \times 10^{-3} \mathrm{mM}$. At a constant BUdR concentration of $0.4 \mathrm{mM}$ the highest obtainable BUdR substitution in one DNA strand is about $70 \%$. As it may be seen from Fig. 2 this substitution is obtained at a tetrahydrofolic acid concentration of $0.3 \times 10^{-5} \mathrm{mM}$. Under these conditions the cellular generation time is rather variable, around 15 hours, and the cell number in

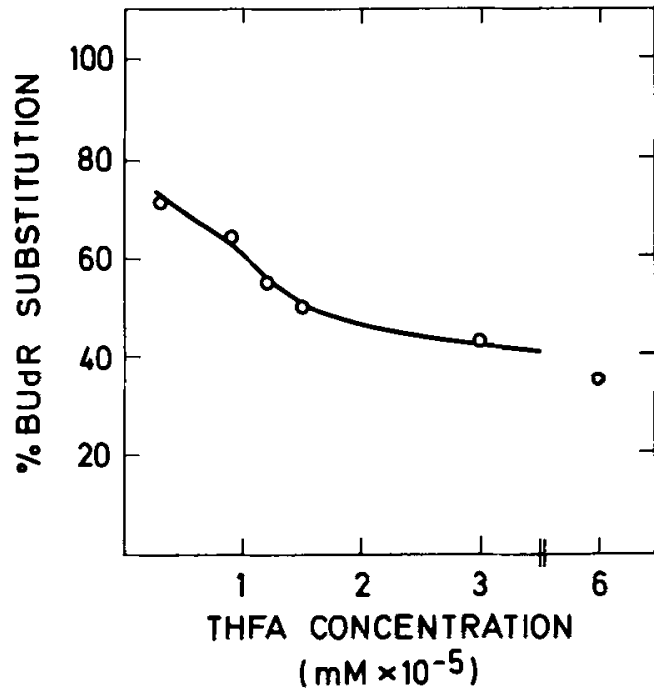

Figure 2. Per cent BUdR substitution in DNA as a function of the tetrahydrofolic acid concentration in the growth medium. BUdR and ${ }^{32} \mathrm{P}$ were added to exponentially growing cultures, which had been prelabelled with ${ }^{3} \mathrm{H}-\mathrm{TdR}$. After the course of two control generation times the cultures were harvested, DNA isolated and analyzed after an equilibrium density gradient centrifugation in $\mathrm{CsCl}$. Per cent BUdR substitution in DNA was estimated as described in Materials and Methods.

stationary phase is about $10^{4}$ cells $/ \mathrm{ml}$ as compared to $5 \times 10^{\mathrm{s}} / \mathrm{ml}$ at optimal tetrahydrofolic acid concentration. Therefore, using the lowest mentioned concentration of tetrahydrofolic acid it is difficult to obtain exponential growth with cell concentrations (at least 2,000 cells $/ \mathrm{ml}$ ) suitable for experiments, and only few such experiments are available.

Total substitution with BUdR for thymidine has not been attained. Apparently Tetrahymena pyriformis synthesizes thymine compounds also when thymidine or BUdR are present in fairly high concentration in the growth medium. In most of these experiments a compromise was accepted: tetrahydrofolic acid concentration, BUdR substitution and cell generation time were $1.5 \times 10^{-5} \mathrm{mM}$, maximally $50 \%$ and about 5 hours, respectively. The degree of BUdR substitution in one DNA strand as a function of the BUdR concentration in the medium $\left(1.5 \times 10^{-5} \mathrm{mM}\right.$ tetrahydrofolic acid per $\mathrm{ml}$ ) is shown in Fig. 3 . 


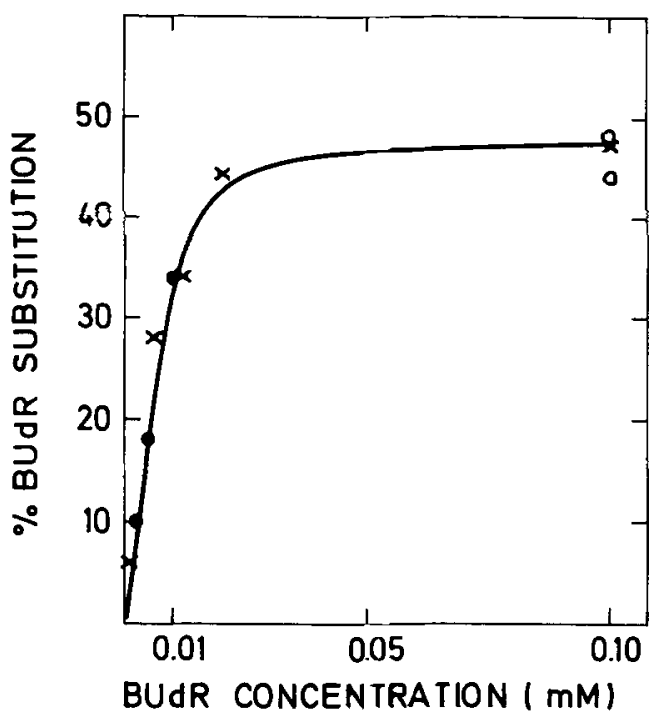

Figure 3. Per cent BUdR substitution in DNA as a function of the $B U d R$ concentration in the growth medium (THFA conc, $1.5 \times 10^{-1} \mathrm{mM}$ ). BUdR and ${ }^{32} \mathrm{P}$ were added to exponentially growing cultures and after the course of two control generation times, the cultures were harvested, DNA isolated and analyzed after an equilibrium density gradient centrifugation in CsCl. Per cent BUdR substitution in DNA was estimated as described in Material and Methods.

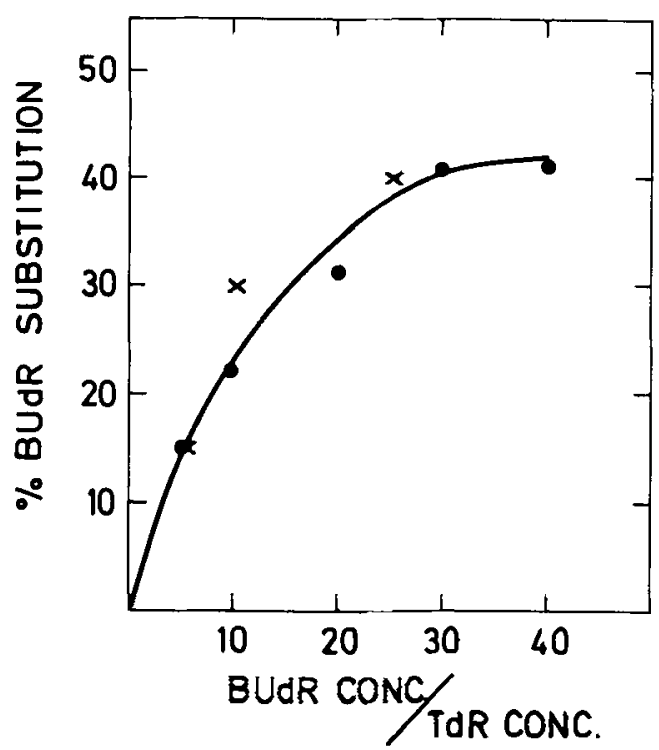

Figure 4. Per cent BUdR substitution in DNA as a function of the BUdR/TR proportion in the growth medium (THFA conc. $1.5 \times 10^{-5} \mathrm{mM}$ ). BUdR + TdR (total conc. $0.1 \mathrm{mM}$ ) was added simultaneously with ${ }^{32} \mathrm{P}$ to exponentially growing cultures, and the cultures treated as described for Fig. 2.
Varying degress of BUdR substitution in DNA can also be obtained keeping a total concentration of $B U d R+T d R$ in the medium and varying the proportion between the concentrations of $B U d R$ and $T d R$, as shown in Fig. 4. Under these conditions the maximal degree of BUdR substitution $\left(1.5 \times 10^{-s} \mathrm{mM}\right.$ tetrahydrofolic acid in the medium) is $40-50 \%$, again revealing a rather high endogenous synthesis of thymidylate. With a ratio of $B U d R / T d R$ of 10 (Fig. 4) the observed rather low BUdR substitution indicates a preference of $T d R$ over $B U d R$, at the level of transport into the cell or with respect to metabolic handling. Such preference is demonstrated by the following experiment. Addition of ${ }^{14} \mathrm{C}$ - $\mathrm{TdR}(0.025 \mu \mathrm{Ci} / \mathrm{ml}$ culture $)$ to a culture containing $0.1 \mathrm{mM} B U d R$, and to one with $0.1 \mathrm{mM} \mathrm{TdR}$, led to a fifteen times higher incorporation of ${ }^{14} \mathrm{C}-\mathrm{TdR}$ into trichloroacetic acid precipitable material per hour per cell in the BUdR than in TdR culture. Thus there is preferential utilization of $T d R$. Consequently the proportion of concentrations in the growth medium of TdR and BUdR does not indicate proportions in utilization of the two compounds.

The effect of BUdR on cell multiplication, DNA synthesis, RNA synthesis and protein synthesis shall be shown as functions of the degree of BUdR substitution in DNA, and for each experiment shall be mentioned the method by which the BUdR substitution has been controlled. The degree of substitution refers to per cent BUdR substitution in one or both strands.

Cell parameters have been followed over one or two doubling times in the control culture (supplied equimolar concentration of TdR). Increases in cell number and amounts of DNA, RNA and protein during the first control doubling time after addition of BUdR are shown in Figs. 5, 7, 9, 12 and 14. The same increases during the second doubling in the control population are shown in Figs. 6, 8, 10, 13 and 15 .

\subsubsection{The effect of $B U d R$ on cell multiplication.}

The effect of BUdR on cell multiplication over the first control doubling time is illustrated in Fig. 5. BUdR substitutions below $50 \%$ are obtained by varying the concentration of tetrahydrofolic acid (usually $1.5 \times 10^{-5} \mathrm{mM}$ ) 
keeping BUdR constant at $0.8 \mathrm{mM}$. BUdR substitutions not exceeding $25 \%$ permit many generations of growth in BUdR, however with increased doubling times after a few generations. Substitutions not exceeding $40 \%$ allow a first doubling, but not a second, in the course of a control cell doubling time. Ultimately cell multiplication ceases in cultures with BUdR substitution between $25 \%$ and $40 \%$. Fourty to $60 \%$ substitution of thymine with bromouracil affects cell multiplication in the first generation, and above $60 \%$ substitution cell multiplication rates reach zero much before all cells have divided. In fact only $20 \%$ of the cells may divide. Assuming that the dividing cells were in G2, and perhaps also in late $S$, when first exposed to BUdR it is suggested that no cell can divide after it has synthesized more than small amounts of nuclear DNA with more than $60 \%$ of the thymine places filled with BUdR.

\subsubsection{The effect of BUdR on DNA synthesis}

The effect of BUdR on DNA replication is shown in Figs. 7 and 8. According to Fig. 7 the first round of DNA replication in BUdR progresses normally, even if bromouracil is built into $70 \%$ of the thymine sites of one DNA strand. These cultures have been prelabelled with ${ }^{3} \mathrm{H}-\mathrm{TdR}$ and then incubated with $\mathrm{BUdR}$ for the time taken for the control culture to double its cell number. Subsequently, the DNA was isolated and the degree of DNA replication measured by $\mathrm{CsCl}$ density gradient centrifugation. In all cases all ${ }^{3} \mathrm{H}$-label was found in the hybrid density DNA indicating that all DNA had replicated one time during a control generation time.

The second replication round in BUdR lags behind the control, (Fig. 8), and the question is asked if this reflects extension of the replication phase in all or most cells, or reduced participation of the cells in DNA replication with little or no change in the rate of progression of a replication round once it is initiated.

To elucidate this question the number of cells in DNA synthesis over consecutive 1-hour intervals were followed by autoradiography, and the synthetic activity of the population as a whole was followed by pulse incorporations of

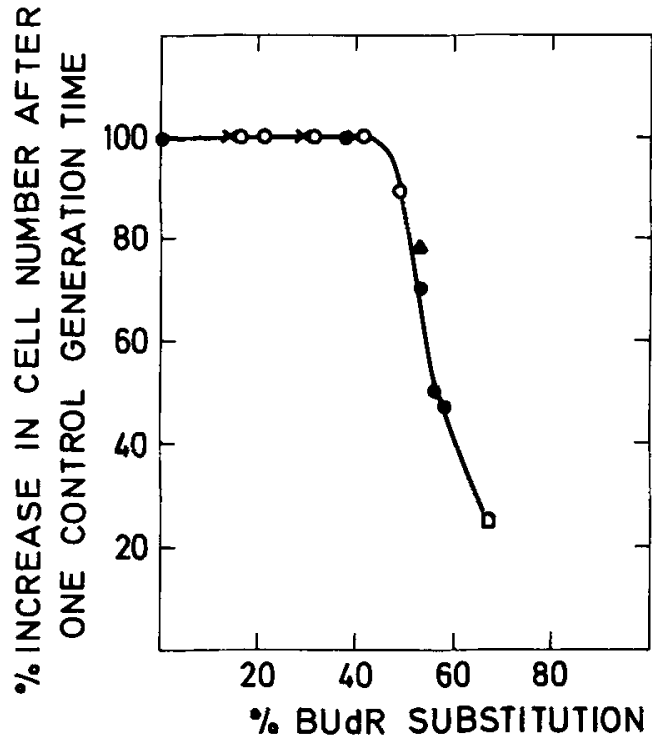

Figure 5. Per cent increase in cell number a control generation time after the supply of BUdR or BUdR + $T d R$ as a function of the BUdR substitution in DNA. BUdR or BUdR + TdR was added to exponentially growing cultures, and the cell number followed until the control culture had doubled in cell number.

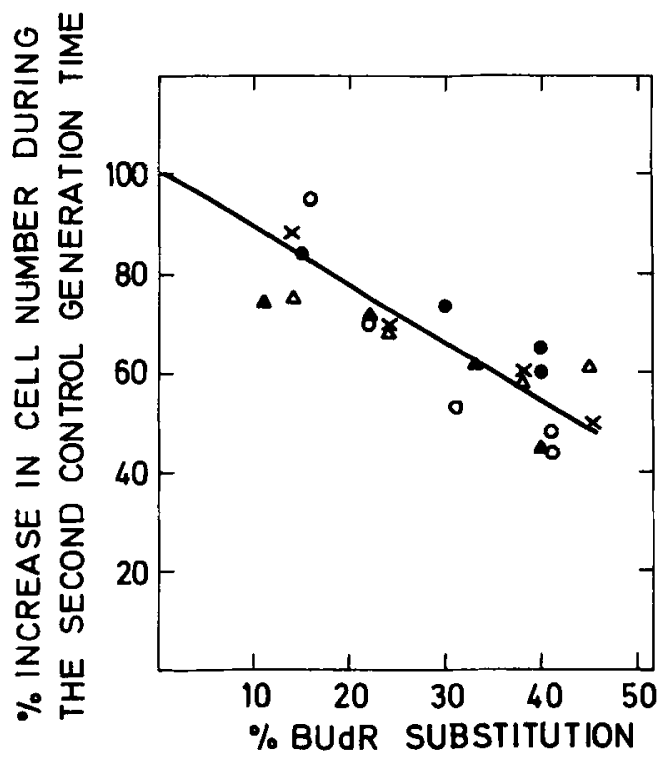

Figure 6. Per cent increase in cell number during the course of the second control generation time as a function of the BUdR subsitution in DNA. BUdR or BUdR + TdR was added to exponentially growing cultures, and the cell number followed until the control culture had doubled in cell number twice. The per cent increase in cell number in course of the second control generation time was estimated. 


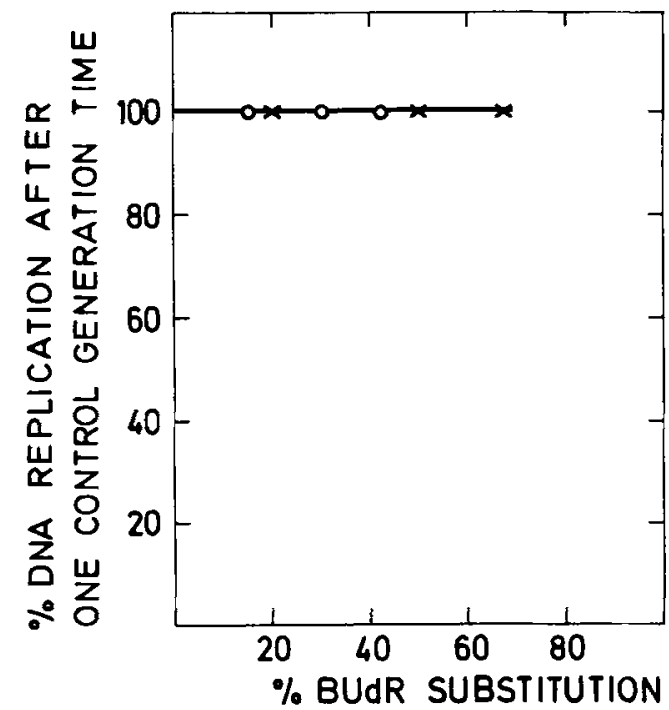

Figure 7. Per cent DNA replication as a function of per cent BUdR substitution in DNA. BUdR or BUdR + TdR was added together with ${ }^{32} \mathrm{P}$ to exponentially growing cultures, which had been prelabelled with ${ }^{3} \mathrm{H}-\mathrm{TdR}$. When the cell number in the control culture had doubled the corresponding BUdR culture was harvested, DNA isolated and separated by equilibrium density gradient centrifugation in $\mathrm{CsCl}$. As well the ${ }^{3} \mathrm{H}$-label as the ${ }^{32} \mathrm{P}$-label was found in the gradient in the position of hybrid DNA.

${ }^{14} \mathrm{C}$-thymidine and scintillation counting. This permitted calculation of rates of DNA synthesis per nucleus engaged in such synthesis at any time. The results are in Table I. They show parallel decreases during the second control generation time of total synthesis of DNA and of nuclei engaged in synthesis. In other words, the rate of synthesis per active nucleus is constant through the second control generation

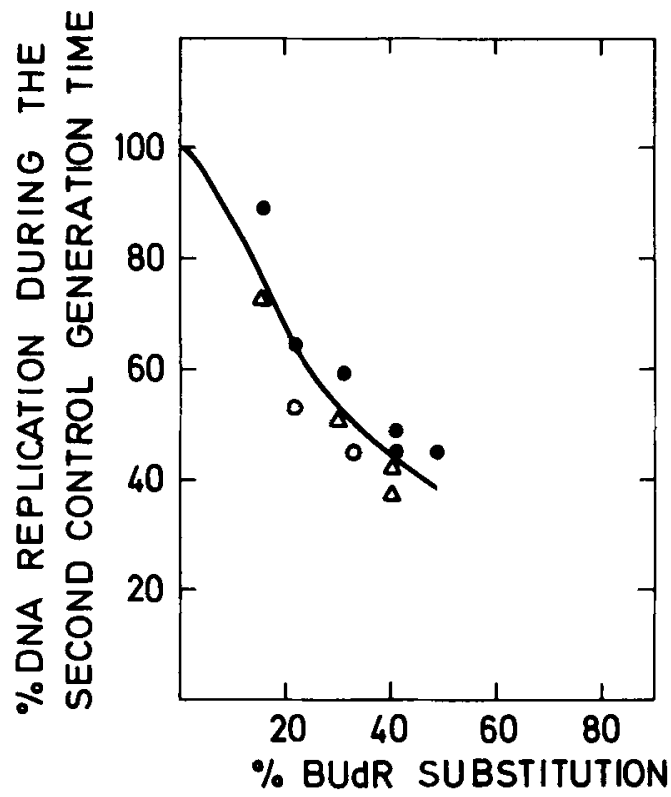

Figure 8. Per cent DNA replication in course of the second control generation time as a function of the BUdR substitution in DNA. BUdR or BUdR + TdR was added together with ${ }^{32} \mathrm{P}$ to exponentially growing cultures, and after the course of two control generation times, the cultures were harvested, DNA isolated and separated by equilibrium density gradient centrifugation in $\mathrm{CsCl}$. The amount of ${ }^{32} \mathrm{P}$ in double heavy and hybrid DNA was determined and per cent replication estimated as described in ref. 38 .

time and identical with the rate of DNA synthesis in the first control generation time. The conclusion from these investigations is that the DNA synthetic rate in the second replication round in BUdR is for an active nucleus normal, but that reduced numbers of cells initiate a second replication round in course of a normal

Table I

\begin{tabular}{|c|c|c|c|c|c|c|}
\hline Hours after addition of BUdR & 1.5 & 2.5 & 5.5 & 6.5 & 9.5 & 12.0 \\
\hline Number of cells pr. ml culture & 75000 & 88000 & 113000 & 123000 & 138000 & 145000 \\
\hline$\%$ cells with labelled nucleus & $75 \%$ & $68 \%$ & $64 \%$ & $61 \%$ & $39 \%$ & $17 \%$ \\
\hline Number of cells pr. ml with labelled nucleus & 56000 & 60000 & 72000 & 75000 & 54000 & 25000 \\
\hline Cpm. pr. ml culture pr, hour & 23000 & 22000 & 28000 & 24000 & 21000 & 9000 \\
\hline Cpm. pr. labelled cell pr. hour & 0.41 & 0.37 & 0.39 & 0.32 & 0.39 & 0.36 \\
\hline
\end{tabular}

The generation time in this experiment was 5.5 hours. BUdR substitution $50 \%$. 


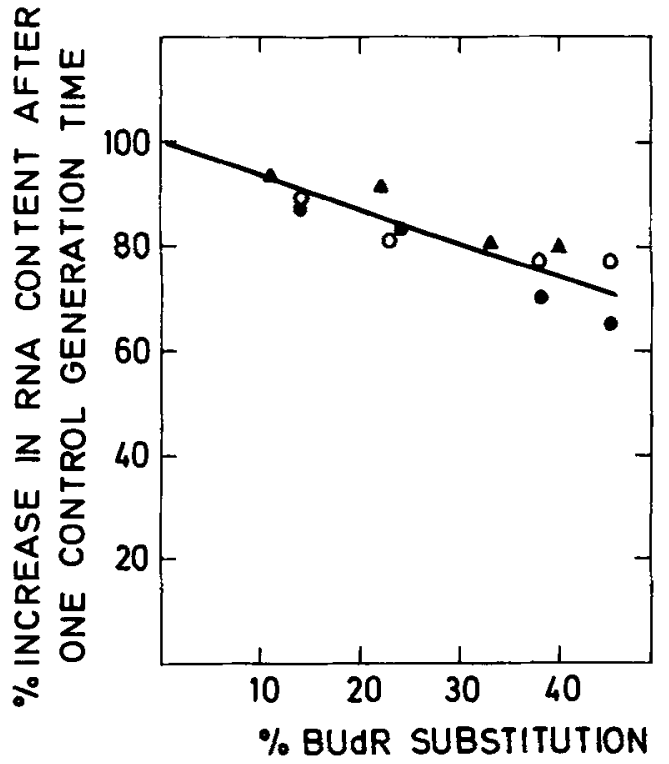

Figure 9. Per cent increase in amount of RNA during the first control generation time with BUdR in the growth medium as a function of per cent BUdR substitution in DNA. BUdR or BUdR + TdR was added to exponentially growing cultures, and each hour samples were withdrawn for determination of the chemical amount of RNA. The per cent increase in chemical amount of RNA after the course of the first control generation time was estimated. The per cent BUdR substitution was determined from subcultures, to which ${ }^{32} \mathrm{P}$ was added immediately after the addition of $\mathrm{BUdR}$, and the subcultures treated as described for Figure 2.

generation time. Thus the observed extension of the second generation time in BUdR cultures can not be due to extension of the Sphase. It rather reflects partial inhibition, by BUdR incorporated in one DNA strand, of the initiation event of the following replication round.

\subsubsection{The effect of BUdR on RNA synthesis}

In these experiments BUdR was added to a number of cultures under conditions which result in different degrees of BUdR substitution. The major variables were the concentrations of $B U d R$ and $T d R$, and the ratio between their concentrations. The results are referred to a first (Fig 9) and a second period (Fig. 10) after BUdR was added, each corresponding to the time it takes for cell

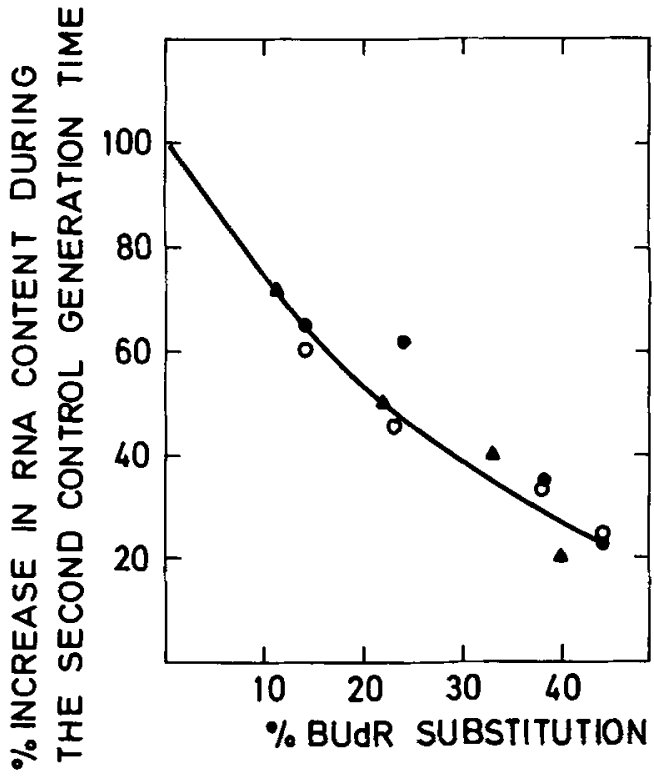

Figure 10. Per cent increase in amount of RNA during the course of the second control generation time as a function of the per cent BUdR substitution in DNA. BUdR or BUdR + TdR was added to exponentially growing cultures and the chemical amount of RNA determined each hour. The per cent increase in amount of RNA during the course of the second control generation time was estimated. Per cent BUdR substition was measured and estimated as described for Figure 9.

numbers and RNA to double in the untreated control culture. Figs. 9 and 10 demonstrate inhibition of RNA synthesis in the first and the second control doubling time, each time in proportion to the degree of substitution of BUdR in the new DNA. RNA synthesis is far more sensitive to BUdR after the incubation time has been extended from one to two control generation times. I can be concluded that RNA synthesis is far more sensitive to BUdR substitution than is DNA synthesis (Figs. 7, 8) and cell division (Figs. 5,6).

The degrees of BUdR substitution shown in Figs. 9 and 10 are achieved by use of different concentrations of BUdR in the growth medium and at this stage the possibility can not be ruled out that BUdR inhibits RNA synthesis directly. To settle this question the rate of RNA synthesis was measured a control generation time 


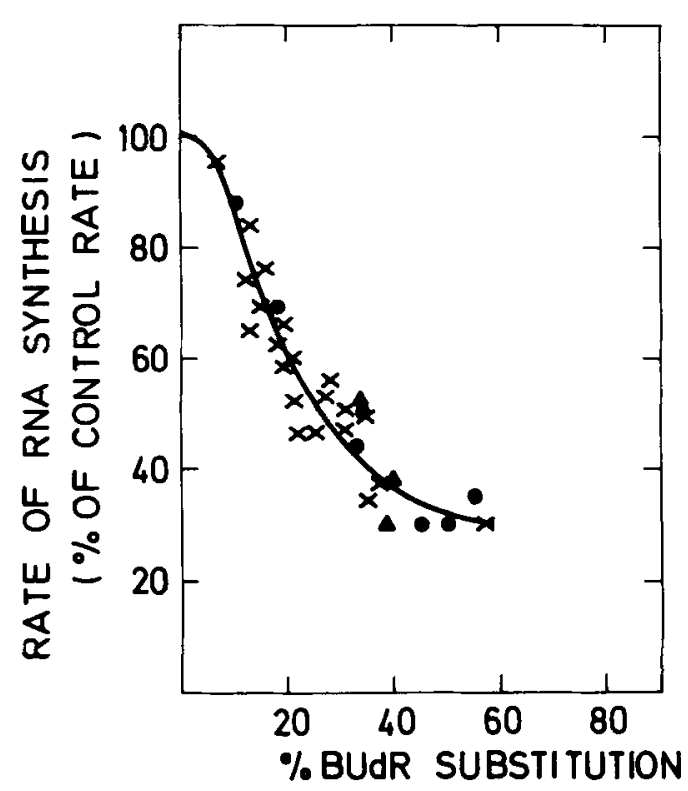

Figure 11. The rate of RNA synthesis (measured as per cent of the rate of RNA synthesis in the corresponding control culture) as a function of the per cent BUdR substitution in DNA. BUdR or BUdR $+\mathrm{TdR}$ was added to exponentially growing cultures, and after the course of the first control generation time, $0.1 \mu \mathrm{Ci}{ }^{14} \mathrm{C}$-uridine was added to $1 \mathrm{ml}$ samples and the amount of acid precipitable ${ }^{14} \mathrm{C}$-uridine incorporated during 45 minutes determined. Per cent BUdR substitution was measured and estimated as described for Figure 9.

after supply of BUdR. The measured degrees of BUdR substitution were obtained by use of all three methods described earlier. In Fig. 11 each method has its own symbol, but regardless of symbols all experiments can be fitted with one curve. These experiments make direct effects of BUdR on RNA synthesis unlikely. All degrees of inhibition of RNA synthesis can occur at a fixed concentration of BUdR in the growth medium, and the same inhibition can be obtained with different concentrations of BUdR. Apparently, therefore, the extent of inhibition of RNA synthesis depends on the degree of BUdR substitution in DNA - and this can be regulated by change of only one factor, the concentration of tetrahydrofolic acid in the medium. To further investigate the problem if BUdR inhibits RNA synthesis by means apart

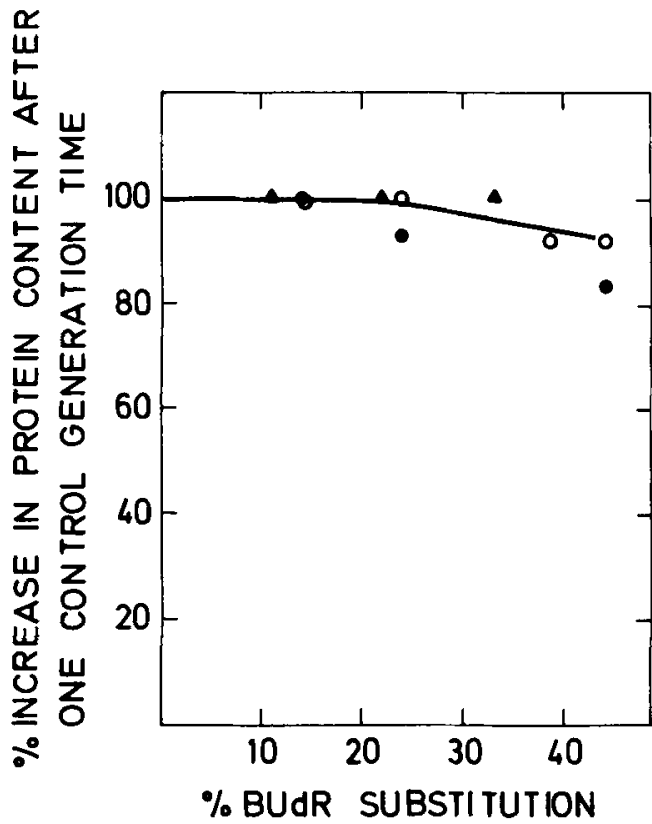

Figure 12. Per cent increase in the amount of protein after the duration of the first control generation time with BUdR in the growth medium as a function of the BUdR substitution in DNA. BUdR or BUdR + TdR was added to exponentially growing cultures, and each hour samples were withdrawn for determination of the protein content. The per cent increase in the amount of protein during the course of the first control generation time was estimated. Per cent BUdR substitution in DNA was measured and estimated as described for Figure 9.

from its incorporation into DNA, synchronously growing populations have been used. This will be described later.

\subsubsection{The effect of BUdR on protein synthesis}

Protein synthesis is nearly unaffected for a period of one normal cell generation after BUdR has been added (Fig. 12) but it is affected after the cells have had the opportunity of incorporating BUdR for a period of one normal cell generation. This is demonstrated by Fig. 13 which refers to measurements of protein accumulation in the second control generation after supply of BUdR. 


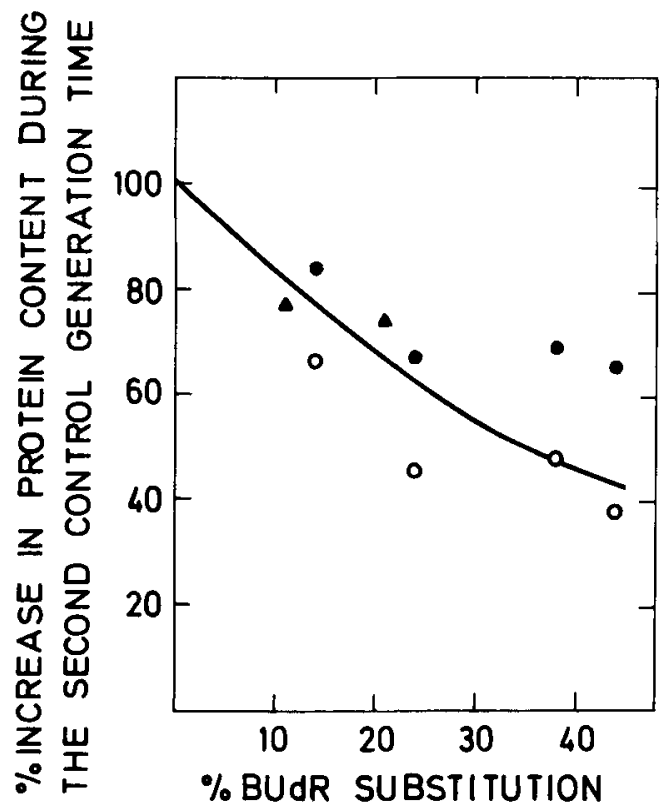

Figure 13. Per cent increase in the amount of protein in course of the second control generation time as a function of the per cent BUdR substituton in DNA. BUdR or BUdR + TdR was added to exponentially growing cultures, and each hour samples were withdrawn for determination of the protein content. The per cent increase in the amount of protein in course of the second control generation time was estimated. Per cent BUdR substitution in DNA was measured and estimated as described for Figure 9.

\subsubsection{A summary of the effects of BUdR on exponentially growing populations}

Effects of BUdR on cell multiplication, DNA-, RNA-, and protein synthesis are shown in Figs. 14 and 15 of which the first deals with cellular responses within the first normal cell generation time after addition of BUdR, and the second describes effects measured in the second control generation. Fig. 14 illustrates that RNA synthesis is immediately sensitive to BUdR, that protein synthesis is only slightly affected and that cell multiplication and DNA synthesis are unaffected at the BUdR substitutions indicated. Measurements of RNA synthesis are not available with BUdR substitution above $50 \%$. However, RNA synthesis can be assumed to be severely inhibited under such conditions, and this may explain why only a

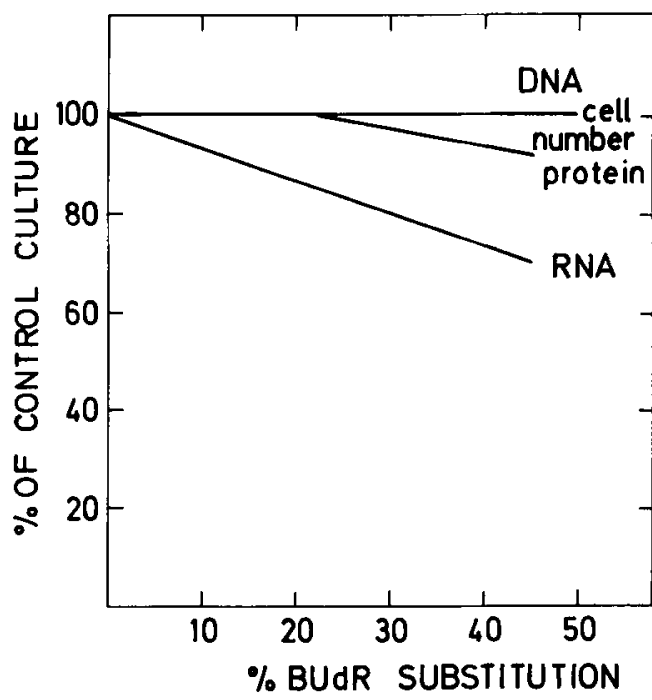

Figure 14. The effect of BUdR on increase in cell number, DNA-, RNA- and protein synthesis in course of the first control generation time as a function of the BUdR substitution in DNA. The increase in the measured cell parameter is shown as per cent of the increase of the corresponding cell parameter in the control culture. This figure is a summary of Figures 5 , 7,9 and 12 .

minor fraction of the cells divides when BUdR substitution exceeds $60 \%$. Since no inhibition of DNA synthesis seems to take place during the first control generation time, one may assume that BUdR functions efficiently as a precursor for DNA replication, and that effects on RNAand protein synthesis, as well as on cell multiplication are graded reflections af graded substitutions in DNA of thymine with BUdR.

Fig. 15 demonstrates delayed effects of $B U d R$. It may be seen that the time required for a second DNA replication round in BUdR much exceeds the time taken for a control population to double its chemical and cellular entities. In this system extensions of doubling times for cells and for DNA may be parallel. If so, the frequencies of cell division and of the initiation of DNA synthesis are similarly reduced. Apparently, DNA replication once in progress in the single cell displays itself at normal rate. This demonstrates that substitution of DNA with BUdR in one strand has no effect on the rate of DNA replication. In the replication 


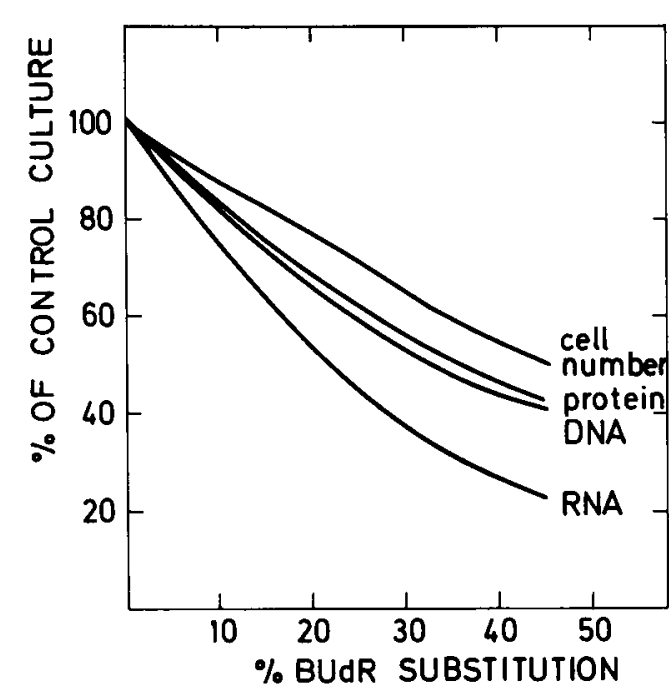

Figure 15. The effect of BUdR on the increase in cell number, DNA-, RNA- and protein synthesis in course of the second control generation time as a function of the BUdR substitution in DNA. The increase in the measured cell parameter is shown as per cent of the increase of the corresponding cell parameter in the control culture. This figure is a summary of Figures 6, 8, 10 and 13.

process the hybrid DNA molecule is perfectly useful as template. Other investigations have demonstrated that DNA with high amounts of BUdR in both DNA strands $(60 \%$ substitution in both) does not function as template for DNA replication; great structural changes of this highly substituted DNA have been demonstrated (38).

The demonstrated inhibitions by BUdR of protein synthesis might reflect inhibitions of RNA synthesis. However, protein synthesis is less affected than total RNA synthesis. This lack of parallel inhibition may reflect one or more of the following conditions: 1) The half lives of mRNA are in excess of $10 \mathrm{~min}$, the published value (54) 2) mRNAs may exist in the cell in considerable excess, and 3) under the conditions of the present experiments mRNA synthesis may be less inhibited than total RNA synthesis. The latter topic is under study.

As mentioned earlier, in all instances an increasing inhibition of the measured cell parameters parallels increasing degress of BUdR substitution in DNA, indicating that the

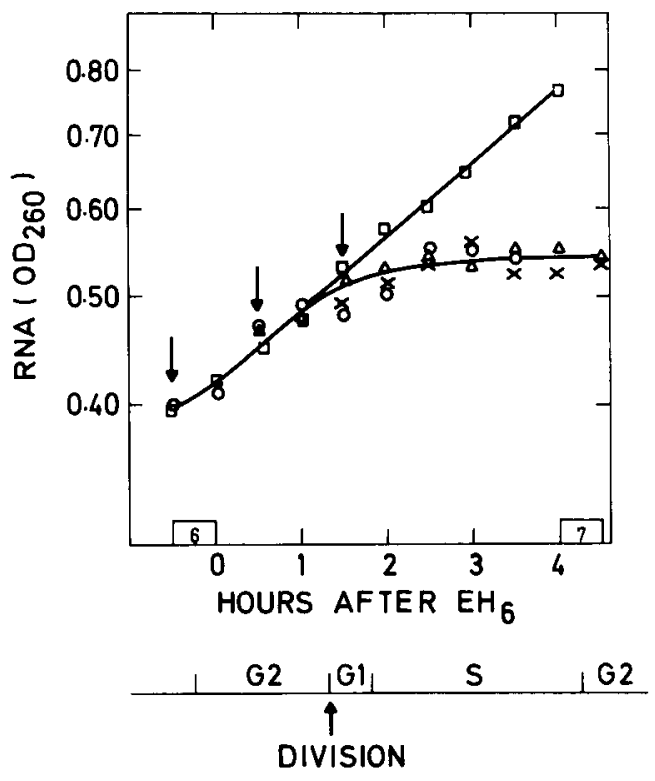

Figure 16. The relative amount of RNA in cultures to which BUdR (final conc. $0.8 \mathrm{mM}$ ) was added at different time points in the cell cycle as a function of the time after the sixth heat shock. The amount of RNA in the control culture $(0.8 \mathrm{mM} \mathrm{TdR})$ is shown by the signature ( $\square$ ). The amount of RNA in the subcultures is shown by the signatures: (0) BUdR added at the onset of heat shock no. $6,(\Delta)$ BUdR added 0.5 hour after the end of heat shock no. 6 and (x) BUdR added 1.5 hours after the end of heat shock no. 6 . The cell cycle is drawn underneath the figure.

effect of BUdR expresses itself through substituted DNA. However, the described experiments for which have been used exponentially growing cell populations do not exclude effects of BUdR not arising from the incorporation of this analogue into DNA. An in vitro system to measure transcription, or synchronously growing populations can be used to further investigate, whether BUdR has effects without being incorporated in the DNA.

\subsection{Synchronously multiplying cells}

2.4.1 The effect of BUdR on synchronously dividing populations

In vitro transcription from Tetrahymena DNA with homologous RNA polymerase (23, 32) has not yet been very successful. However, problems which might be solved by use of in vitro transcription may often as well be 
approached by experiments with synchronously growing populations. Several methods to induce synchronous growth of Tetrahymena pyriformis are available (3), and two were chosen: heat shock treatment as reported by ZEUTHEN (58) and starvation-refeeding as described by CAMERON and JETER (10).

Subcultures in different stages of the cell cycle were obtained by sampling a heat synchronized population. The first sample was drawn at the end of the S-period, the second in the middle of the G2-period, and the third just before the onset of the next S-period (Fig. 16). The subcultures were immediately supplied BUdR. RNA was measured chemically in samples from the subcultures and from the control culture. Fig, 16 demonstrates that the RNA synthesis proceeds unaffected by BUdR until around the time when the S-period begins in BUdR. At this time the accumulation, by synthesis, of RNA ceases abruptly; it continues in the control. Thus the three subcultures show sharply curtailed RNA synthesis at the same time point in the cell cycle regardless of the time for which BUdR has been present in the medium. This experiment indicates that $B U d R$ is without effect on the synthesis of RNA until it has been incorporated into DNA.

From Fig. 16 can be suggested that reduction in RNA synthetic rate develops rapidly after the onset of the S-period. This is confirmed by the experiment in Fig. 17 which demonstrates correlation between progression of DNA replication and development of inhibition of RNA synthesis proceeds unaffected by BUdR inhibitor was supplied in $\mathrm{G} 2$, and the curves show per cent of DNA replication with time and rates of RNA synthesis per unit of time.It is seen that the rate of RNA synthesis in BUdR occurs at control rate as long as DNA synthesis has not yet been initiated. However, $10 \%$ and $50 \%$ replication of the DNA is accompanied by $35 \%$ and $65 \%$, respectively, decrease in the rate of RNA synthesis. From this is suggested that inhibition of RNA synthesis occurs in response to incorporation of BUdR into DNA and in particular into genes which replicate early in the DNA synthetic period. Genes which code for ribosomal RNA do this (2) and it is tempting to speculate that incorporation of $B U d R$ into

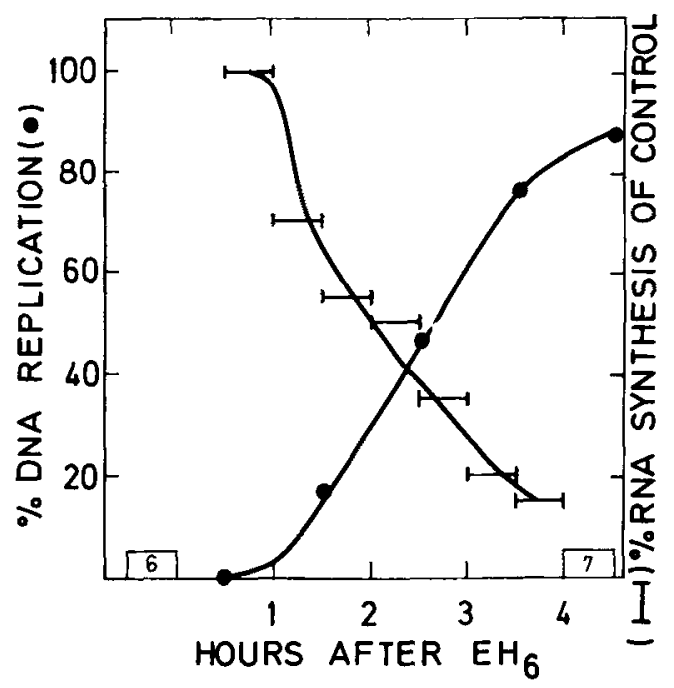

Figure 17. DNA replication ( $\bullet$ ), after addition of BUdR to a culture treated with heat shocks to induce synchronous division, and rate of RNA synthesis, $(-)$, expressed as percentage of the RNA synthesis in a control culture. BUdR was added at time 0.5 hour.

the ribosomal genes strongly inhibit their transcription (39).

Using cultures induced to synchronous cell division by starvation and refeeding it was shown that the RNA synthesis is unaffected of BUdR in the growth medium as long as the cells do not synthesize DNA (39). Fig. 18 shows the result of an experiment in which a starved culture was supplied BUdR with the fresh growth medium. For the first 5.5 hours the rates of RNA synthesis are identical in BUdR and control (equimolar TdR) cultures, but then the rate decreases steeply in the BUdR culture. This drop in the rate of RNA synthesis sets in shortly after the onset of the DNA replication. It has been found that in a population induced to synshronous cell divisions by the starvation-refeeding method $45 \%$ of the genes which code for ribosomal RNA are replicated when only $16 \%$ of the bulk DNA has been through replication (17), indicating that also in this synchronized system replication of rDNA takes place early in the S-period. Studies with both synchronized systems therefore lead to the conclusion that incoporation of BUdR into genes coding for ribosomal RNA leads to rapid 

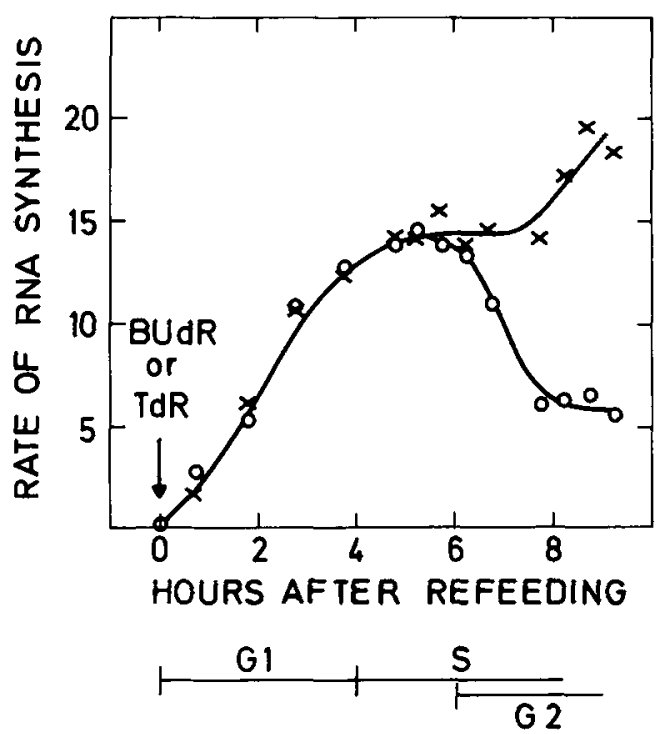

Figure 18. Rate of RNA synthesis as a function of the time after refeeding of a starved culture. Immediately after refeeding, BUdR was added to one subculture, $T d R$ to another (final conc. $0.8 \mathrm{mM}$ ). The incorporation of ${ }^{14} \mathrm{C}$-uridine into acid precipitable material per $\mathrm{ml}$ culture per 0.5 hour was determined. The cell cycle is drawn underneath the figure. The overlap between the $S$ period and the $G 2$ period indicate the rather poor synchrony.

reduction in ribosomal and total RNA synthesis.

\subsubsection{A summary of the effects of BUdR on syn- chronized populations}

Studies with two different Tetrahymena systems with induced cell synchrony lead to the conclusion that incorporation of BUdR into early replicating DNA causes inhibition of RNA synthesis. In both systems the genes which code for ribosomal RNA replicate early in the S-epriod. It has been proposed that inhibition of total RNA synthesis mainly reflects inhibition of transcription of BUdR-substituted ribosomal genes (39). It should be noted that ribosomal RNA constitutes up to $90 \%$ of all RNA in Tetrahymena (33).

These experiments exclude major direct effects of BUdR on RNA synthesis, thus also on the RNA polymerase which transcribes the ribosomal genes. The possibility should not be entirely dismissed, however, that BUdR acts indirectly on this enzyme by contaminating its genes which perhaps replicate early in $S$. However, this should cause at the most $50 \%$ inhibition of RNA synthesis in the first cell generation exposed to BUdR, and up to $80 \%$ inhibition was observed. The observed correlation between contamination of early replicating DNA with BUdR and inhibition of RNA synthesis may have more than one cause. It may reflect the summation of effects at the transcriptional level af many early replicating genes.

\subsection{Effects of BUdR on the synhesis of specific} RNA.

Isolation of total RNA by phenol extraction followed by centrifugation in a linear 0.15 $0.58 \mathrm{M}$ sucrose gradient gives three peaks of RNA, the first containing $25 \mathrm{~S}$ ribosomal RNA, the second $17 \mathrm{~S}$ ribosomal RNA and the third a mixture of $5 \mathrm{~S}$ ribosomal RNA, tRNA and mRNA. The genes which code for the two large ribosomal RNAs (25S and 17S) are located in the nucleoli (18) and are often referred to as ribosomal genes. These genes replicate autonomously (2). The $5 \mathrm{~S}$ RNA genes are not nucleolar and replicate with the bulk DNA (55). In Tetrahymena tRNAs have sedimentation constants around $4 \mathrm{~S}$ and they are not separable form $5 \mathrm{~S}$ ribosomal RNA by the method here used. Messenger RNAs (mRNA) have sedimentation constants from $23 \mathrm{~S}$ to $4 \mathrm{~S}$ clustering around $10 \mathrm{~S}(54)$, but they amount to only a few per cent of the total RNA.

In the following experiment RNA was generally labelled by growth for several generations of the cells in ${ }^{3} \mathrm{H}$-uridine. This culture was divided into two subcultures after removal of ${ }^{3} \mathrm{H}$-uridine from the medium. Th: subcultures were incubated for one normal generation time with BUdR (experimental) or equimolar TdR (control). At the beginning of the second generation in BUdR (TdR) the growth medium was further enriched with ${ }^{32}$ P-phosphate. After $45 \mathrm{~min}$ the cells were harvested, RNA isolated and analyzed in density gradients as described (Fig. 19 A, B). In A and $B$ the gradient analysis shows similar dis- 
tributions in the gradients of bulk RNA prelabelled with ${ }^{1} \mathrm{H}$, but BUdR and control cultures differ with respect to densities of RNA synthesized in the presence or in the absence of BUdR. This RNA is labelled with ${ }^{32} \mathrm{P}$. The control (A) shows little difference in RNA profiles obtained with ${ }^{3} \mathrm{H}$ and with ${ }^{32} \mathrm{P}$ as the label, but the presence of BUdR (B) leads to increase in RNA fractions with sedimentation constants lower than $17 \mathrm{~S}$. Radioactivity measurements across the profiles indicate that in the BUdR culture the synthesis of 25 S RNA and $17 \mathrm{~S}$ RNA are reduced to $29 \%$ and $33 \%$, respectively, of the rate of the control culture, whereas the synthesis of RNA with sedimentation constants below $17 \mathrm{~S}$ occurs at $63 \%$ of the control rate. Thus, syntheses of the two large ribosomal RNA species seem almost identically inhibited, and far more than the synthesis of smaller RNAs (sedimentation constants $<17$ ). It is as yet unknown how the species of RNA in the latter group are affected relative to each other. Presently is concluded that growth in BUdR leads to preferential inhibition of the synthesis of $25 \mathrm{~S}$ and $17 \mathrm{~S}$ ribosomal RNA compared to the group of smaller RNAs (5 S RNA, tRNA, and mRNA).

As illustrated earlier (Fig. 9-11) BUdR-substituted DNA supports rates of RNA synthesis which vary inversely with the level of substitution. In Fig. 20 the abscissa shows RNA synthesis expressed as \% of the control rate. This percentage varies considerably and is obtained by way of a broad range of BUdR substitutions. In the same graph the ordinate accounts for the effects of BUdR, in the same experiments, on the rate of synthesis of each of the three fractions into which the techniques used separate the cellular RNA. Equal percentage inhibition by BUdR of total (abscissa) and specific RNA synthesis (ordinate) would place observations of the latter on the dashed line sloping $45^{\circ}$. However, the observations indicate that some RNA species are less (sedimentation constants $<17$ ), some more ( $25 \mathrm{~S}$ and $17 \mathrm{~S}$ ribosomal RNA) inhibited than total RNA. It may be concluded that all measured degrees of BUdR substitution in DNA cause preferential inhibition of the synthesis of 25S and 17S RNA, and that inhibition
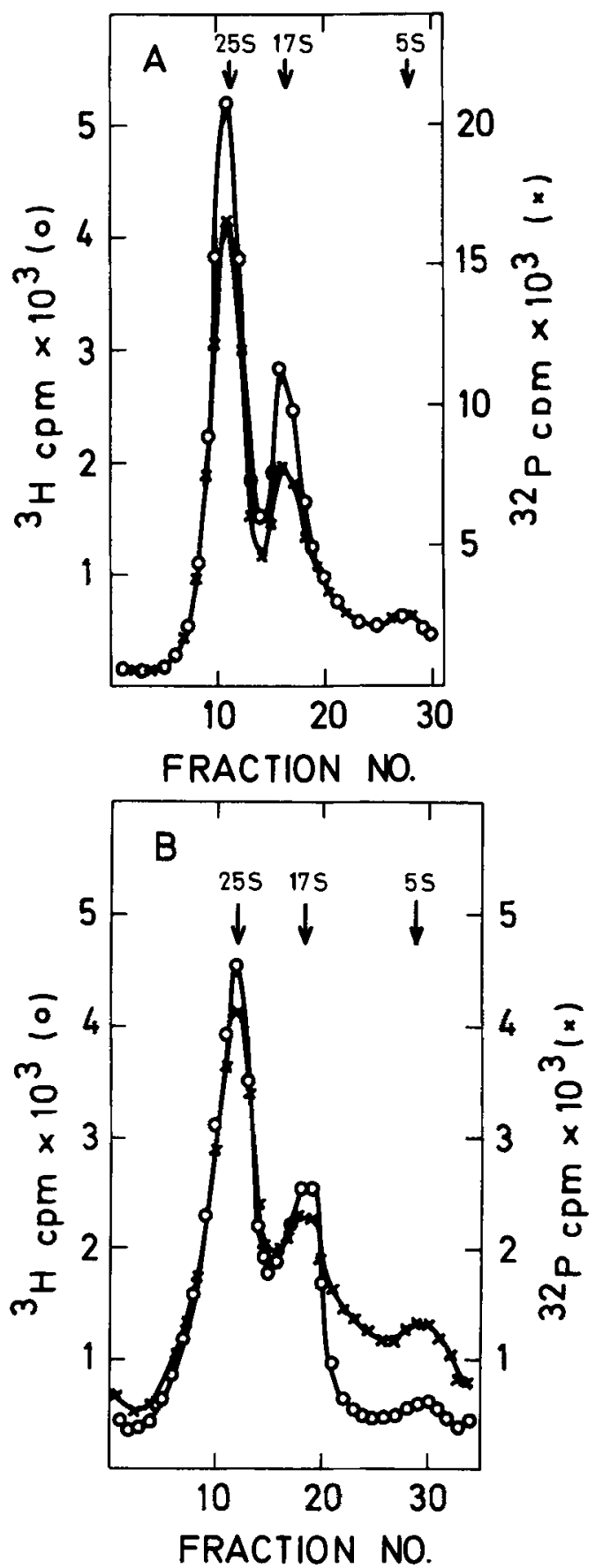

Figure 19. The distribution of radioactively labelled RNA after centrifugation in a linear $0,15-0,58 \mathrm{M}$ sucrose gradient. A culture, prelabelled with ${ }^{3} \mathrm{H}$-uridine was divided into two. TdR was added to the one (A), BUdR to the other (B), final conc. $0.01 \mathrm{mM}$. After the course of a control generation time ${ }^{32} \mathrm{P}(2 \mu \mathrm{Ci} / \mathrm{ml}$ culture) was added to both cultures, and 45 minutes later both cultures were harvested. Total RNA was isolated by a phenol extraction. 


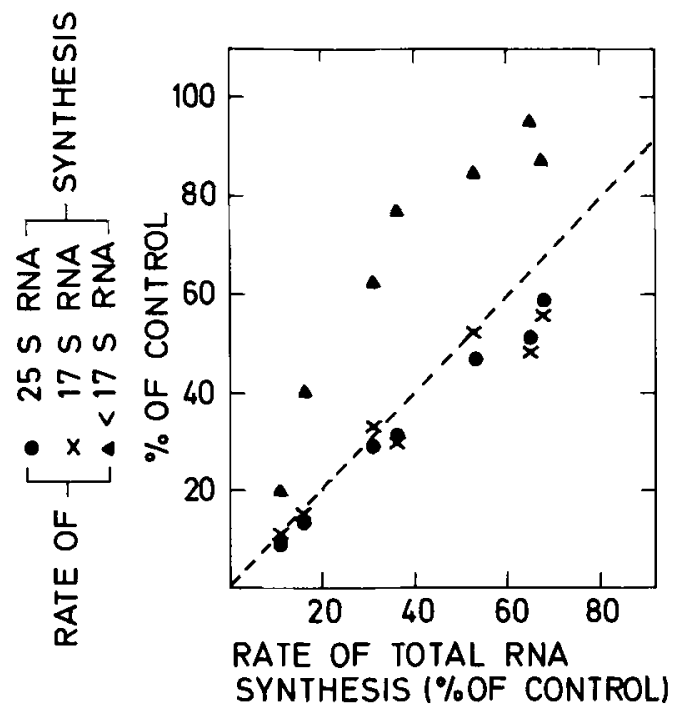

Figure 20. The synthetic rate of 25 S RNA, 17 S RNA and RNA having sedimentation constants below $17 \mathrm{~S}$ in cultures grown with BUdR (the synthetic rate is expressed as per cent of the syntethic rate of the corresponding RNA species in the control culture) as a function of the rate of total RNA synthesis in these cultures (The rate of total RNA synthesis in the BUdR cultures is expressed as per cent of the rate of total RNA synthesis in the corresponding control culture). Cultures with different BUdR concentrations are grown as described for figure 19, and the synthetic rate is estimated from the amount of ratioactivity in the respective groups of RNA isolated from a BUdR culture and the corresponding control culture.

is nearly equal for the two large ribosomal RNAs (41).

In Tetrahymena pyriformis genes coding for $25 \mathrm{~S}$ and 17S RNA are located in nucleoli in the periphery of the macronucleus (18) The DNA in the nucleolus is not in physical contact with other macronuclear DNA, and recently it has been shown (16) that each nucleolus contains two sequences of 245 - 17S RNA genes. $25 S$ RNA and 17S RNA have a common precursor RNA molecule with a sedimentation constant of $45 \mathrm{~S}$, and their synthesis must be initiated from a common promotor (34).

The clear separation of $25 \mathrm{~S}$ and 17S RNA shown in Fig. 19 supplies no evidence of the existence of unfinished transcription products or of partially degraded 25S RNA. Furthermore, there is equal inhibition of $25 \mathrm{~S}$ and $17 \mathrm{~S}$ ribosomal RNA synthesis at all levels of BUdR substitution. These observations, taken together, lend support to the view that BUdR substitution inhibits the initiation of the synthesis of the precursor 45S RNA molecule.

\section{SUMMARY AND CONCLUSIONS.}

BUdR affects Tetrahymena only after it has been incorporated into DNA in considerable amounts. Shortly after it has been incorporated reduction can be observed in the rate of RNA synthesis, and this appears to cause delayed inhibition of protein synthesis and of cell multiplication. DNA replication for at least two rounds is undisturbed in the single cells, but the initiation of the second round occurs with delay, and this reflects on the population.

BUdR incorporation into DNA affects the synthesis of different RNAs differently. Synthesis of $25 \mathrm{~S}$ and $17 \mathrm{~S}$ ribosomal RNA are preferentially inhibited.

It is proposed that $\mathrm{BUdR}$ incorporated into DNA exerts the described effects by affecting chromatin structure differentially throughout the genome, and that this leads to change in the normal pattern of transcripts produced by the cells.

Most described effects of BUdR can be interpreted by this model. Enzyme activities may be affected differentially because BUdR substitutions from gene to gene corresponds to differences in base sequence.

Observed inhibition of cellular differentiation by BUdR may be a consequence of a change in the pattern of transcription, and the high sensititivy to even low BUdR substitution may reflect that minor changes in the pattern of transcription perturb the normal development of a differentiating system.

How structural changes in the DNA molecule lead to changes in the pattern of transcription is not understood. One can imagine that RNA polymerases may be sterically hindered from transcribing DNA regions containing high amounts of BUdR, or that change in the binding of regulatory proteins to BUdR-substituted DNA is involved. Further in- 
vestigations will be needed to shed light on these problems.

\section{ACKNOWLEDGEMENTS}

The work has been carried out at The Biological Institute of the Carlsberg Foundation, Copenhagen, Denmark, and was supported by the Carlsberg Foundation. The staff of the Institute and the head, Professor E. ZEUTHEN, are hereby thanked for good working conditions and stimulating discussions. A special thank is addressed to Dr. H. A. ANDERSEN for excellent collaboration and to Dr. E. ZEUTHEN for valuable criticism of the manuscript.

\section{REFERENCES}

1. Аввот, J. \& H. Holtzer: The loss of phenotypic traits by differentiated cells. V: The effect of 5-bromodexyuridine on cloned condrocytes. Proc. Nat. Acad. Sci. 52, 1144-1151 (1968)

2. Andersen, H. A. \& J. Engrerg: Timing of the ribosomal gene replication in Tetrahymena pyriformis. Exp. Cell Res. 92, 159-163 (1975)

3. ANdersen, H. A., L. Rasmussen \& E. Zeuthen: Cell division and DNA replication in synchronous Tetrahymena cultures. Current Topics in Microbiology and Immunology 72, 1-20 (1975)

4. Augenlicht, L., C. Nicolini \& R. Baserga: Circular dichroism and thermal denaturation studies of chromatin and DNA from BUdR treated mouse fibroblasts. Biochem. Biophys. Res. Com. 59, 920-926 (1974)

5. Benzer, S. \& E. Freese: Induction of specific mutations with bromouracil. Proc. Nat. Acad. Sci. 44, 112-119(1958)

6. BICK, M. D. \& R. L. Davidson: Total substitution of bromodeoxyuridine for thymidine in the DNA of a bromodeoxyuridine-dependent cell line. Proc. Nat. Acad. Sci. 71, 2082-2086 (1974)

7. Bischoff, R. \& H. Holtzer: Inhibition of myoblast fusion after one round of DNA synthesis in 5-bromodeoxyuridine. J. Cell Biol. 44, 134-150(1970)

8. Bцоom, S. E. \& T. C. Hsu: Differential fluorescence of sister chromatids in chicken embryos exposed to 5-bromodeoxyuridine. Chromosoma 51, 261-267(1975)

9. BraUn, R. \&. H. WILI: Time sequence of DNA replication in Physarum. Biochem. Biophys. Acta 174, 246-252 (1962)
10. Cameron, I. L. \& J. R. Jr. Jeter: Synchronization of the cell cycle of Tetrahymena by starvation and refeeding. J. Protozool. 17, 429-431 (1970)

11. Dahlberg, J. E., K. Perk \& A. J. Dalton: Virus-like particles induced in guinea pig cells by 5-bromodeoxyuridine are morphologically similar to murine B-type virus. Nature 249, 828-830 (1974)

12. David, J., J. S. Gordon \& W. J. Rutter: Increased thermal stability of chromatin containing 5-bromodeoxyuridine substituted DNA. Proc. Nat. Acad. Sci. 71, 2808-2812 (1974)

13. Dickens, M. S., J. LuCas-Lenard \& J. S. Roth: Induction of thymidylate syntetase activity in Tetrahymena by cyclic guanosine monophosphate. Biochem. Biophys. Res. Com. 67, 1319-1325 (1975)

14. DunN, D. B. \& J. D. Smith: Incorporation of halogenated pyrimidines into the deoxyribonucleic acids of Bacterium coli and its bacteriophages. Nature 174, 305-306 (1954)

15. Dutrillaux, B., A. M. Fosse, M. Prieur \& J. LEJEUNE: Analyse des echanges de chromatides dans les cellules somatique humaines. Traitement au BUdR (5-bromodeoxyuridine) et fluorescence bicolore par l'acridine orange. Chromosoma 48, 327-340 (1974)

16. Engberg, J., P. Andersson, V. Leick \& J. Collins: The free rDNA molecules from Tetrahymena pyriformis, GL are giant palindromes. I. Mol. Biol. 104, 455-470 (1976)

17. Engberg, J., D. Mowat \& R. E. Pearlman: Preferential replication of the ribosomal RNA genes during a nutritional shift up in Tetrahymena pyriformis. Biochem. Biophys. Acta 272, 312-320 (1972)

18. Engberg, J., J. R. Nilsson, R. E. Pearlman \& V. LEICK: Induction of nucleolar and mitochondrial DNA replication in Tetrahymena pyriformis. Proc. Nat. Acad. Sci. 71, 894-989 (1974)

19. FABIAN; B. \& F. WILT: The incorporation of 5-bromodenxyuridine into DNA of the areas Opaca Vasculosa of chick embryos. Dev. Biol. 32, 92-100 (1973)

20. FoGEL, M.: Induction of polyoma virus by flurescent (visible) light in polyoma-transformed cells pretreated with BUdR. Nature 241, 182-184 (1973)

21. Gordon, J. A., J. W. David, G. Bell, J. B. MCCARTHY \& W. J. RUTTER: Altered properties of chromatin containing the thymidine analog 5-bromodeoxyuridine. J. Cell Biol. 59, 116a (1973) 
22. Gratzner, H. G., R. C. Leif, D. J. Ingram \& A. CASTRO: The use of antibody specific for bromodeoxyuridine for the immunofluorescent determination of DNA in single cells and chromosomes. Exp. Cell Res. 95, 88-94 (1975)

23. Higashinakagawa, T. \& T. Mita: Novel features of DNA-dependent RNA polymerase from protozoan Tetrahymena pyriformis. Febs Letters 25, 73-76 (1972)

24. Hill, B. T., A. Tsubol \& R. Baserga: Effect of 5-bromodeoxyuridine on chromation transcription in confluent fibroblasts. Proc. Nat. Acad. Sci. 71, 455-459 (1974)

25. Hitchings, G. H., E. A. Falco \& M. B. SHERWOOD: The effect of pyrimidines on the growth of Lactobacillus casei. Science 102, 251-252 (1945)

26. Holtzer, H., H. Weintraub, R. Mayne \& B. MoCHaN: The cell cycle, cell lineages and cell differentiation. Current Topics in Developmental Biology 7, 229-256 (1972)

27. Hsu, T. C. \& C. E. SOMERs: Effect of 5-bromodeoxyuridine on mammalian chromosomes. Proc. Nat. Acad. Sci. 47, 396-403 (1961)

28. Hutchinson, F.: The lesions produced by ultraviolet light in DNA containing 5-bromouracil. Quarterly Review of Biophysics 6, 201-246 (1973)

29. JoNes, T. C. \& W. F. DOVE: Photosensitization of transcription by bromodeoxyuridine substitution. J. Mol. Biol. 64, 409-416 (1972)

30. Keiding, J. \& O. WestergaARD: Induction of DNA polymerase activity in irradiated Tetrahymena cells. Exp. Cell Res. 64, 317-322 (1971)

31. Koyama, H. \& T. ONO: Induction of alkaline phosphatase by 5-BUdR in a hybrid line between mouse and chinese hamster in culture. Exp. Cell Res. 69, 468-470(1971)

32. LeE, Y. C. \& J. E. ByfleLd: Characteristics of in vitro ribonucleic acid synthesis by maronuclei of Tetrahymena pyriformis. Biochemistry 9, 3947-3959 (1970)

33. LEICK, V.: Growth rate dependency of protein and nucleic acid composition of Tetrahymena pyriformis and the control of synthesis of ribosomal and transfer RNA. Compt. Rend. Trav. Lab. Carlsberg 36, 113-125 (1967)

34. LEICK, V.: Formation of subribosomal particles in the macronuclei of Tetrahymena pyriformis. Eur. J. Biochem. 8, 221-228(1969)

35. LIN, S. \& A. RIGGS: Lac operator analogues: Bromodeoxyuridine substitution in the lac operator affects the rate of dissociation of the lac repressor. Proc. Nat. Acad. Sci. 69, 2754-2576 (1972)
36. Lowry, O. H., N. J. Rosebrough, A. L. FARR, \& R. J. Randall: Protein measurement with the Folin phenol reagent. J. Biol. Chem. 193, 265-275 (1957)

37. LYKKESFELDT, A. E.: Effect of 5-bromodeoxyuridine on Tetrahymena pyriformis grown in low concentrations of tetrahydrofolic acid. Compt. Rend. Trav. Lab. Carlsberg 40, 91-100 (1974)

38. LyKKESFELDT, A. E. \& H. A. ANDERSEN: The effect of 5-bromodeoxyuridine on DNA replication and cell division in Tetrahymena pyriformis. J. Cell Biol. 62, 316-321 (1974)

39. LykKesfeldt, A. E. \& H. A. ANDERSEN: Inhibition of rRNA synthesis following incorporation of 5-bromodeoxyuridine into DNA of Tetrahymena pyriformis. J. Cell Sci. 17, 495-502 (1975)

40. Lykkesfeldt, A. E. \& H. A. Andersen: Studies on the molecular basis for inhibition of cell proliferation by 5-bromodeoxyuridine. In: Progress in Differentiation Research, Elsevier, North Holland, Biomedical Press, B. V. p. 71-76 (1976)

41. LyKKesfeldt, A. E. \& H. A. ANDERSEN: Preferential inhibition of rDNA transcription by 5-bromodeoxyuridine. J. Cell Sci. In press.

42. Meselson, M., F. W. Stahl \& J. Vinograd: Equilibrium sedimentation of macromolecules in density gradients. Proc. Nat. Acad. Sci. 43, 581-585 (1957)

43. Miura, Y. \& F. WILT: The effects of 5-bromodeoxyuridine on yolk sac erythropoiesis of the chick embryo. J. Cell Biol. 48, 523-532 (1971)

44. Moroni, C., G. Schumann, M. Robert-Guroff \& E. R. SUTER: Induction of endogenous murine C-type virus in spleen cell cultures treated with mitogens and 5-bromo-2'-deoxyuridine. Proc. Nat. Acad. Sci. 72, 535-538 (1975)

45. Rasmussen, L. \& L. Modeweg-Hansen: Cell multiplication in Tetrahymena cultures after addition of particulate material. J. Cell Sci. 12, 275-286 (1973)

46. Rutter, W. J., R. L. Pictet \& R. W. Morris: Toward molecular mechanisms of developmental processes. Ann Rev. Biochem. 42, 601-646 (1973)

47. Schildikraut, C. L., J. Marmur \& P. Doty: Determinition of the base composition of deoxyribonucleic acid from its buoyant density in CsCl. J. Mol. Biol. 4, 430-443 (1962)

48. Schwartz, S. A., S. Panem, E. Stefanski \& W. H. KIRSTEN: Endogenous type $C$ particles from rat embryo cells treated with 5-bromodeoxyuridine. Cancer Res. 34, 2255-2259 (1974) 


\section{A. E. LYKKESFELDT: Effects of BUdR on Tetrahymena pyriformis}

49. Silagi, S., D. Beju, J. Wrathall \& E. DEHARVEN: Tumorigenicity, immunogenicity and virus production in mouse melanoma cells treated with 5-BUdR. Proc. Nat. Acad. Sci. 69, 3443-3447 (1972)

50. Stambrook, P. \& R. Williamson: Error frequency in 5 S RNA from cells grown in 5-bromodeoxyuridine. Eur. J. Biochem. 48, 297-302 (1974)

51. Stellwagen, R. H. \& G. M. Tomkins: Differential effect of 5-bromodeoxyuridine on the concentration of specific enzymes in Hepatoma cells in culture. Proc. Nat. Acad. Sci. $68,1147-1150(1971)$

52. Sellwagen, R. H. \& G. M. Tomkins: Preferential inhibition by 5-bromodeoxyuridine of the synthesis of tyrosine aminotransferase in Hepatoma cell cultures. J. Mol. Biol. 56, 167-182 (1971)
53. Stockdale, F., K. Okazaki, M. Nameroff \& H. Holtzer: 5-bromodeoxyuridine: Effect of myogenesis in vitro. Science 146, 533-535 (1964)

54. TøNNESEN, T.: Evidence for existence of messenger ribonucleoprotein complexes in Tetrahymena pyriformis. Exp. Cell Res. 76, 273-280 (1973)

55. Tønnesen, T. \& H. A. Andersen: Timing of $5 \mathrm{~S}$ RNA and tRNA gene replication in Tetrahymena pyriformis. In prep.

56. WAKe, R. G. \& R. L. BALDwin: Physical studies on the replication of DNA in vitro. J. Mol. Biol. 5, 201-216 (1963)

57. Wrathall, J. R., C. Oliver, S. Silagi \& E. ESSNER: Suppression of pigmentation in mouse melanoma cells by 5-bromodeoxyuridine. J. Cell Biol. 57, 406-426 (1973)

58. Zeuthen, E.: Synchrony in Tetrahymena by heat shocks spaced a normal generation apart. Exp. Cell Res. 68, 49-60(1971) 